\title{
OPEN Asynchronous multi-decadal time-scale series of biotic and abiotic responses to precipitation during the last 1300 years
}

Sangheon $\mathrm{Yi}^{1,2 \bowtie}$, Chang-Pyo Jun ${ }^{1 凶}$, Kyoung-nam Jo ${ }^{3}$, Hoil Lee $^{1}$, Min-Seok Kim ${ }^{1}$, Sang Deuk Lee ${ }^{4}$, Xianyong $\mathrm{CaO}^{5,6}$ \& Jaesoo Lim $^{1}$

East Asian summer monsoon (EASM)-driven rapid hydroclimatic variation is a crucial factor with major socioeconomic impacts. Nevertheless, decadal- to centennial-scale EASM variability over the last two millennia is still poorly understood. Pollen-based quantitative annual precipitation (PqPann) and annual precipitation reconstructed by artificial neural networks (ANNs) for the period 650-1940 CE were reconstructed from a paleo-reservoir in South Korea. ANNs reconstruction was performed to compensate for a hiatus section. On a decadal timescale, 10 high-precipitation periods were identified, and PqPann and ANNs reconstructions were comparable to local instrumental rainfall and historic drought records. Biotic lags to rapid climatic changes ranging from 25 to 100 years were recognized by asynchronous pollen and speleothem responses to precipitation. We suggest that PqPann-based decadal- to centennial-scale climatic change reconstruction should take biotic lags into account, although the lags can be ignored on the millennial scale. The position of the EASM rainband influenced rainfall magnitude.

Abrupt climatic changes, including extreme events, accompanying global warming over the last two millennia (e.g., Ljungqvist ${ }^{1}$ ) are important, as such events directly affect human life. As an area strongly influenced by the East Asian monsoon system, northeast Asian is characterized by considerable precipitation variability, which leads to frequent dry and wet periods and severe droughts and floods that have major socioeconomic impacts due to their effects on agriculture, etc. The position of the rainband of the East Asian summer monsoon (EASM) is critical to the rapid hydroclimatic variability, which has important effects on society; for example, the collapses of historical Korean and Chinese dynasties was linked to extreme climate events ${ }^{2-8}$.

As the Korean Peninsula (KP), which is located on the East Eurasian continental margin facing the Western Pacific Ocean, is simultaneously affected by both terrestrial and oceanic environmental factors, it has a history of more dynamic climate oscillations than China and Japan ${ }^{9-14}$. Therefore, the KP is an ideal site for studies of East Asian monsoon system activity in East Asia. Due to high and continuous sedimentation and climatic sensitivity, lake (reservoir) sediments and speleothems provide a record of multi decadal- to centennial-scale East Asian monsoon system changes. However, few investigations of lake sediments have dealt with geoecological environmental responses to rapid climatic changes during the mid- to late Holocene in the $\mathrm{KP}^{15-18}$.

We obtained the GG-19-2-1 sediment core from the Gonggeom-ji paleo-reservoir, which was embanked during the Unified Silla dynasty (ca. $700 \mathrm{CE}$ ) for flood control and to provide irrigation for rice cultivation ${ }^{19}$. Age-controlled lithological analysis assumed that the paleo-reservoir was initially formed as a fluvial floodplain at around $2230 \mathrm{cal} \mathrm{yr} \mathrm{BP}$, subsequently changing to a reservoir with a high sedimentation rate $(2-8 \mathrm{~mm} / \mathrm{yr})$ at about 1500 cal yr BP.

\footnotetext{
${ }^{1}$ Korea Institute of Geoscience and Mineral Resources, Daejeon 34132, Korea. ${ }^{2}$ Korea University of Science and Technology (UST), Daejeon 34113, Korea. ${ }^{3}$ Kangwon National University, Chuncheon 24341, Korea. ${ }^{4}$ Nakdonggang National Institute of Biological Resources, Sangju 37242, Korea. ${ }^{5}$ Key Laboratory of Alpine Ecolgoy, Institute of Tibetan Plateau Research, Beijing, China. ${ }^{6}$ CAS Center for Excellence in Tibetan Plateau Earth Sciences, Chinese Academy of Sciences (CAS), Beijing 100101, China. ${ }^{\varpi}$ email: shyi@kigam.re.kr; cpjun@kigam.re.kr
} 
Pollen analysis was carried out to estimate pollen-based quantitative annual precipitation (PqPann) over the last 1300 years (650-1940 CE). However, we found that the GG19-2-1 core has a hiatus, with records missing for the 660 years from 980 to $1650 \mathrm{CE}$. Until now, if a hiatus was present in a sediment succession, it was impossible to reconstruct the paleoenvironment for the corresponding period. To overcome the lack of information, for the first time, we used a machine-learning method (artificial neural networks, ANNs), and a well-established and agecontrolled high-resolution pollen dataset, to reconstruct the quantitative annual precipitation (Pann) during the period 980-1650 CE. Changes in precipitation on the KP over the past 1300 years were reconstructed, including through pollen analysis and covering the hiatus period. When the same statistical technique was applied to the reconstructed pollen-based precipitation and $\delta^{18} \mathrm{O}$ of speleothem data, we found time-series lags between biotic and abiotic responses to rainfall, although they showed similar fluctuation trends. The time-series lags differed between the Medieval Warm Period (MWP) and Little Ice Age (LIA). As no studies on this topic have been published, we discuss the new findings from a geoecological viewpoint. Finally, the reconstructed precipitation data suggested that the magnitude of rainfall differed depending on the location of the EASM rainband over the past 1300 years in Northeast Asia.

\section{Results}

In general, the pollen assemblage over the past 1300 years (Supplementary Figure S2) reflects a mixed forest of conifers and broadleaf deciduous trees dominated by pine (Pinus), oak (Quercus), and apricot (Prunus) in a mountainous area with an understory of ferns. In addition, herbs, including grasses (Poaceae) and sedges (Cyperaceae) associated with riparian willow (Salix), alder (Alnus), and smartweed (Persicaria), grew in lowland areas and along streams. Mountainous trees and shrubs were predominant over the last 1300 years, although the relative proportions of dominant taxa changed over time. The concentration (pollen grains per unit of sediment volume) of the palynoflora increased suddenly at a hiatus depth of $3.5 \mathrm{~m}$, which is the boundary of the local pollen assemblage zone of GG19-III and GG19-IV.

Comparison of Pann and independent data (calculated with 100-year Butterworth low-pass filtering to match the time resolution of dry-wet periods), shown in Figs. 1, 2, indicates that the dry-wet periods could provide a reasonable representation of precipitation change for the calibrated period. The lag times between Pann and the oxygen isotope data were 17.26 years during the MWP and 94.06 years during the LIA (Supplementary Figure S3b, c).

PqPann reconstruction was performed for the periods 1940-1666 and 968-658 CE, which are separated by the hiatus (Supplementary Figure S1). The average PqPann was 1,222 mm/yr (range: $655-1,530 \mathrm{~mm} / \mathrm{yr}$ ) during the period 1940-1666 CE, and $1304 \mathrm{~mm} / \mathrm{yr}$ (range: 770-1,454 mm/yr) during the period 968-658 CE (Fig. 2a, b). The ANNs was used to estimate the Pann for the hiatus period 1650-983 CE, for which pollen data are not available (Fig. 2c). The reconstructed Pann averaged 1,290 mm/yr (range: $670-1,580 \mathrm{~mm} / \mathrm{yr}$ ). The PqPann- and ANNs-reconstructed datasets had similar amplitudes, ranging from 655 to $1,580 \mathrm{~mm} / \mathrm{yr}$. PqPann data were verified by comparison with old (Chukwooki; 1777-1910 CE) and modern (1908-1995 CE) rain gauge data ${ }^{20,21}$, and with the drought frequency in the annals of the Joseon Dynasty $(1400-1890 \mathrm{CE})^{8}$ (Fig. 2a). The relative sand contents (\%) of KL-2922 were used as input variables to estimate the ANNs data and we found good matches (Fig. 2b). Subsequently, a 100-year Butterworth low-pass filter was applied for PqPann (Fig. 2c) and was correlated with that of the $\delta^{18} \mathrm{O}(\%)$ of $\mathrm{BN}-1$ of Baengnyeong Cave ${ }^{9}$, revealing biotic lag ranging from 25 to 100 years (Figs. 2d, 3, and Supplementary Figure S3). With Butterworth low-pass filtering, our data were comparable to those for Lakes Songji ${ }^{18}$ and Hwajinpo ${ }^{16}$, with the exception of a few periods (e.g., 1150-990 CE in Fig. 2e and 1290-1190 CE in Fig. 2f).

\section{Discussion and conclusions}

PqPann and ANNs reconstruction and influencing factors. Over the last decade, PqPann reconstruction has been performed for East Asia ${ }^{23-31}$. The reconstructed dataset suggests that centennial- to millennial-scale dry-wet fluctuations are linked to the variability in the EASM and north-southward migration of the westerly jet stream (WJ) that was teleconnected to the Atlantic Meridional Overturning Circulation during the Holocene.

As an area strongly influenced by the East Asian monsoon system, the KP has characteristically high precipitation variability, leading to higher frequencies and amplitudes of dry and wet periods ${ }^{20}$, and severe, persistent droughts and floods, described in historical documents ${ }^{8}$ (Fig. 2). PqPann and ANNs reconstruction for the period 650-1940 CE in South Korea included 10 centennial-scale wet epochs (light gray bars in Fig. 4a), with multi-decadal dry/wet fluctuations within each epoch (Fig. 4b). The variability and trend of the PqPann and ANNs reconstruction of South Korea (GG19-2-1 and SOJ-2 ${ }^{18}$ ) are comparable to those of northeast China (Lakes Jingpo $^{32}$ and Silhailongwan $\left.{ }^{27}\right)$, but the Korean PqPann amplitudes (655-1530 mm/yr) are higher than those in China (644-949 mm/yr) (Fig. 4a), despite the almost equivalent rainfall duration (Fig. 4b).

The discrepancy in rainfall intensity between the two regions may be due to the difference in distance from the EASM rainband. According to Herzschuh et al. ${ }^{31}$, the EASM rainband that influenced the intensity and amount of precipitation during the late Holocene was located in southeastern China (Fig. 1). Therefore, the KP is much closer to the EASM rainband than is northeast China, so the KP is highly affected by rainfall forcing of the EASM rainband. In comparison with $\mathrm{BN}-1^{9}$ of South Korea, $\delta^{18} \mathrm{O}$ of $\mathrm{HC}^{33}$ for southeastern China had small values, but a higher amplitude (Fig. $4 \mathrm{c}, \mathrm{d}$ ), indicating greater rainfall intensity in southeastern China due to its location within the EASM rainband area (Fig. 1).

Gradual weakening of EASM intensity was detected from the mid to late Holocene ${ }^{34}$, corresponding to a decrease in Northern Hemisphere summer insolation ${ }^{35}$ and enhanced El Niño-Southern Oscillation (ENSO) activity $^{14,36-38}$. However, the solar forcing ${ }^{29}$ and ENSO-driven hydroclimatic variability ${ }^{18,39}$ during the late 


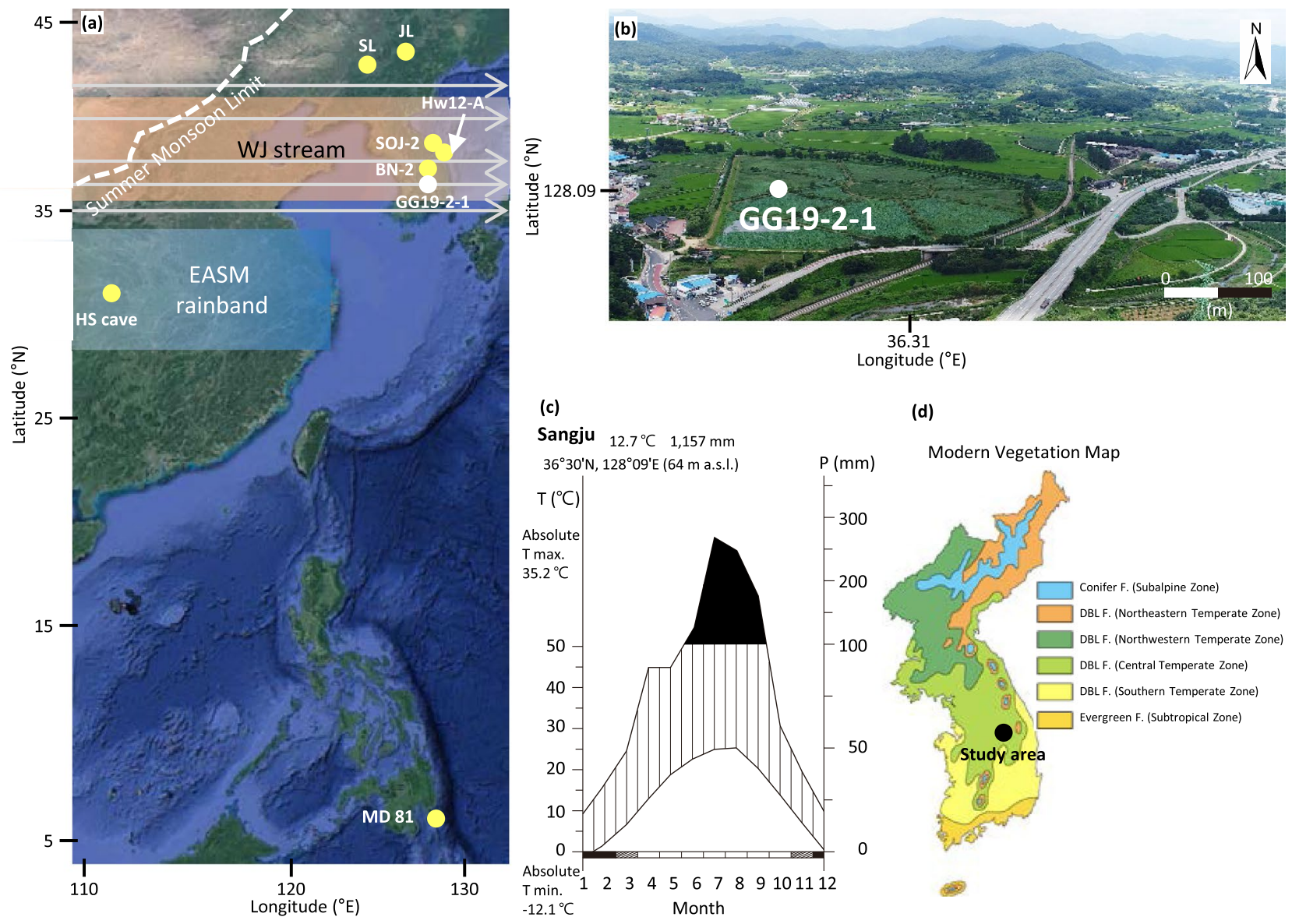

Figure 1. (a) Locations of the GG19-2-1 core site and other sites cited in the text: Hw12-A (Hwajinpo) and SOJ-2 (Songji) lakes, and BN-2 (Baeg-nyeong) cave, South Korea; SL (Silhailongwan) and JL (Jingpo) lakes, northeast China, and HE (Heshang) cave, central China; and MD81 in the western tropical Pacific. These maps were created using Generic Mapping Tools (v.5.4.4, https://www.generic-mapping-tools.org/download/). The dashed line indicates the northernmost extent of the Asian summer monsoon. Position and orientation of the rainband and westerly jet (WJ) stream during the Late Holocene are from Herzschuh et al. ${ }^{31}$ Arrowed grey parallel lines represent the general direction and width of the WJ stream. (b) Aerial photograph of Gonggeom-ji showing the location of the GG19-2-1 core site. (c) Seasonal changes (2002-2019 CE) in temperature and precipitation in the Sangju area, where the Gonggeom-ji paleo-reservoir is located, based on information from the Korea Meteorological Administration (https://data.kma.go.kr). (d) The study area belongs to the central temperate zone of the deciduous broadleaf forest based on the modern vegetation map of Korea (modified from Yim and Kira ${ }^{69}$ ) (drawn using CorelDRAW Graphics Suite X7). DBL F., deciduous broadleaved forest.

Holocene increased the precipitation intensity over the KP, which is located on the East Asian coast. The atmospheric (continental setting) and oceanic (East Asian coast) forcings influencing the multi-centennial dry and wet epochs are recorded in GG19-2-1 (Figs. 4e,f,g).

Biotic lags in response to rapid climate changes. The biotic responses to rapid climate change on a geological timescale around the North Atlantic have been investigated at an intermediate temporal scale ${ }^{40-46}$. Williams et al. ${ }^{40}$ reported that vegetation changes took place $<100$ years after the climatic oscillation, together with major climatic changes. Based on pollen and plant macrofossil data plus oxygen isotope data, $\mathrm{Yu}^{41}$ also provided evidence for replacement of spruce forest by pine within $\sim 100$ years of the beginning of the Holocene warming. These studies documented a response of the plant population to climate change on an intermediate temporal scale that was more gradual than the immediate individual (phenology) response to recent warming ${ }^{47}$. Meanwhile, Post ${ }^{40}$ argued that the responses of plant communities to climate change are as fast as, or even faster than, the responses predicted by the stochastic forest gap models of Lischke et al. ${ }^{48}$, and that the plant population shifts in response to climatic oscillation on the order of decades are equally important in biomes.

The time series of the PqPann GG19-2-1 and $\delta^{18} \mathrm{O}$ data for BN- $1^{9}$ were compared using 100 -year Butterworth low-pass filtering and cross-correlation analysis. Remarkably, the medians of the most highly significant crosscorrelations between the two datasets revealed similar variability, with lags of 25-50 and 50-100 years during the MWP and LIA, respectively (Fig. 3).

In general, the PqPann fluctuations matched temperature anomaly fluctuations in northeast China ${ }^{7}$ (Fig. 4a, f), whereas the time-series variability data of $\delta^{18} \mathrm{O}$ for $\mathrm{BN}-1$ was comparable to the time series solar irradiance ${ }^{49}$ 


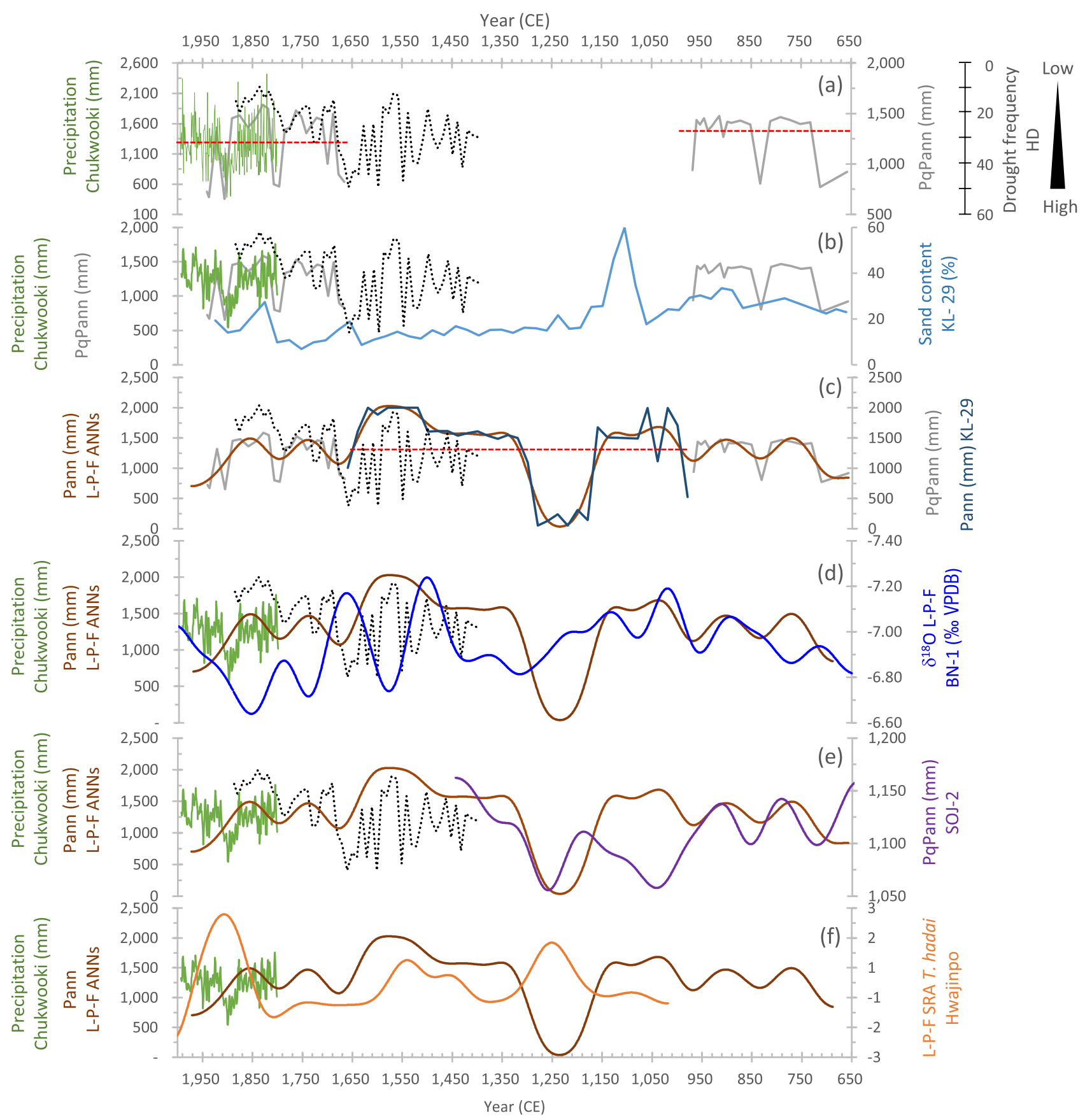

Figure 2. Pollen-based quantitative annual precipitation (PqPann) and artificial neural networks (ANNs) Pann reconstruction from 650 to $1950 \mathrm{CE}$ and their verification by comparison with the Korean proxy results of the relative sand contents (\%) of KL-2922, oxygen isotopes $\left(\delta^{18} \mathrm{O} \% \text { VPDB) of Baeg-nyeong Cave (BN- } 1\right)^{9}$, the foraminifera index ${ }^{16}$, old (Chukwooki; 1777-1910) and modern (1908-1995) rain gauge data ${ }^{20,21}$, and drought records from the annals of the Joseon Dynasty ${ }^{8}$. (a) PqPann (light gray line), old rain gauge data (green line), and frequency of droughts (black dotted line). The red dotted line indicates the average PqPann. (b) PqPann $(\mathrm{mm})$ and sand contents (\%) of KL-29. (c) PqPann (light gray line), Pann of KL-29 (dark blue line), and 100year low-pass-filtered (L-P-F) data (dark brown line) of ANNs. The red dotted line indicates the average ANNs. (d) L-P-F at 100 years ANNs precipitation ( $\mathrm{mm}$ ) of the GG19-2-1 sediment core (dark brown line) and oxygen isotope $\left(\delta^{18} \mathrm{O} \% \mathrm{VPDB}\right)$ of BN-1 (blue line) showing a lag time of ca. $25-100$ years. (e) L-P-F at 100 years PqPann comparison between the northeast coast, Songji Lake ${ }^{18}$, and inland (GG19-2-1, this study) region of the KP. (f) L-P-F at 100 years ANNs and the foraminifera Trochammina hadai from Hwajinpo Lake (drawn using CorelDRAW Graphics Suite X7). 

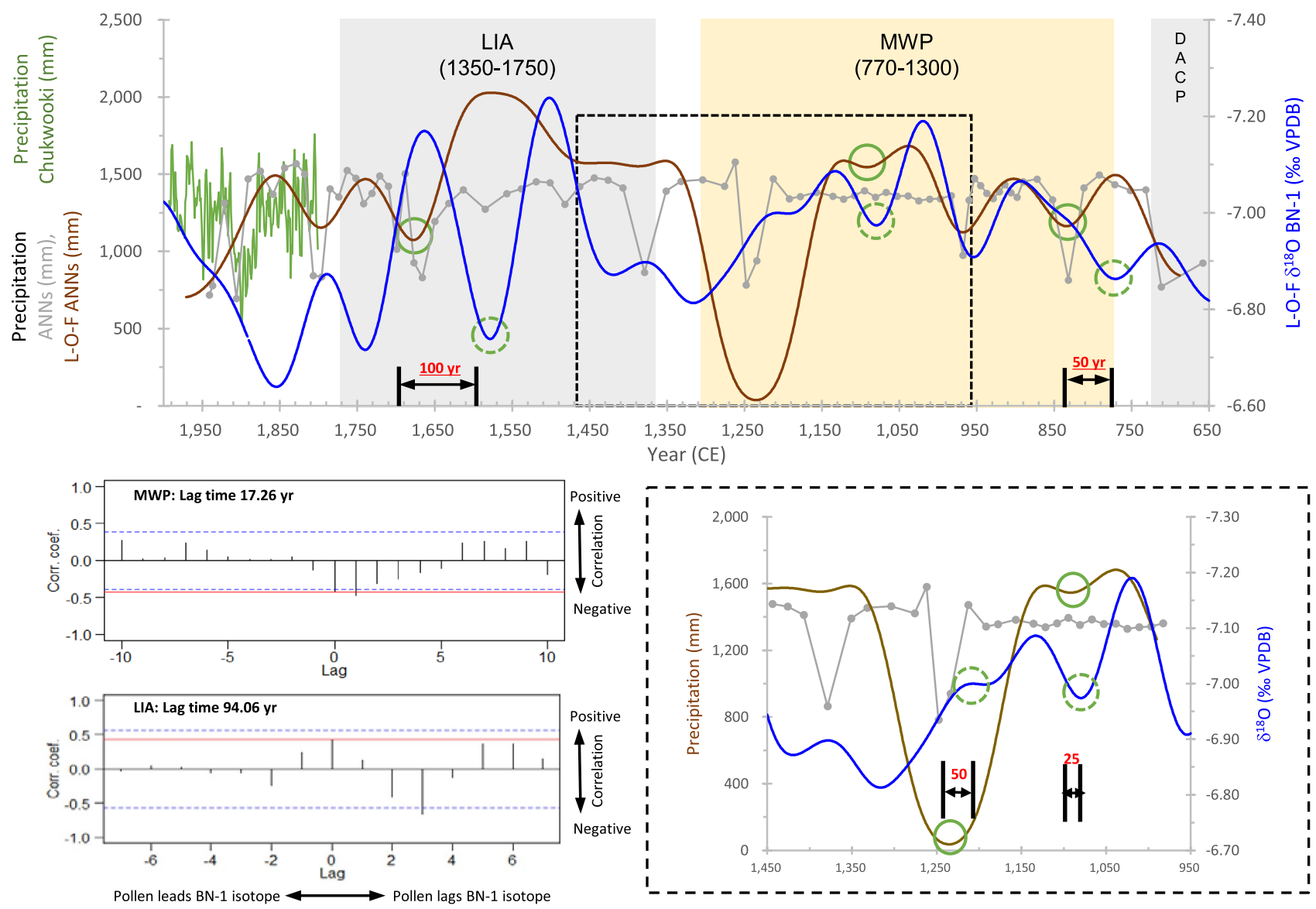

Figure 3. Comparison of 100 -year L-P-F values between the ANNs $(\mathrm{mm})$ and $\mathrm{BN}-1\left(\delta^{18} \mathrm{O} \% \mathrm{VPDB}\right)$ during the period 650-1950 CE. Peaks of BN-1 are about 25-100 years ahead of those of PqPann. Cross-correlation results show that lag times of LIA (94.06 yr) are longer than those of MWP (17.26 yr). The red lines represent the correlation coefficient for lag 0 . Correlation coefficients outside the dashed blue lines are significant at $P=0.05$. Amplitudes from Pann of ANNs and oxygen isotope of BN-1 during the LIA are generally higher than during the MWP in the KP. LIA, Little Ice Age; MWP, Medieval Warm Period; DACP, Dark Age Cold Period (drawn using CorelDRAW Graphics Suite X7).

and sunspot number ${ }^{50}$ data (Fig. 4e), resulting in $\mathrm{BN}-1$ leads with lags in the variation of PqPann. The 10 peaks of PqPann (Fig. 4a) always followed those of BN-1 (Fig. 4c) during the period 650-1940 CE in South Korea, because shifts in plant community responses to abrupt climate changes occurred during multi-decadal dry and wet epochs ${ }^{40,44}$. The response times of plant communities are also dependent on temperature, with warmer and colder periods associated with faster and slower responses, respectively.

We only used pollen data derived from trees and shrubs (arboreal pollen, AP) to reconstruct precipitation, because trees and shrubs are sensitive to climate change, whereas grasses (non-arboreal pollen, NAP) are generally climate-tolerant. In Korea, mountain areas have been used for slash-and-burn agriculture to secure fields for cultivation $^{51,52}$. In mountain areas, the forests are mainly trees and shrubs, and are influenced by human interference, changes in the spectrum of AP, and enhanced surface soil erosion, which all increase the sedimentation rate $^{53}$. By contrast, in the study area, riverine herbs and aquatic and cultivated grasses occupied the lowlands and paleo-reservoir (paleo-wetland). In addition, at the time of the analysis, the study area was mainly used for rice paddy farming ${ }^{54}$. Therefore, we inferred that the trees and shrubs used to reconstruct precipitation were relatively unaffected by human activities; therefore, the trees and shrubs likely responded to changes in the natural environment. Ammann et al. ${ }^{55}$ reported that the individual responses of plant species to climatic changes may reflect processes in individuals (e.g., productivity and phenology) and populations (e.g., population dynamics), as well as spatial distributions (e.g., migrations). Our pollen data suggested effects of the first two processes only, as the study area has the geomorphological characteristics of a small basin surrounded by hills and low mountains.

Considering that speleothem $\delta^{18} \mathrm{O}$ records rapidly reflect water-controlled abiotic processes in the atmosphere (vadose zone), they can signal hydroclimatic changes with much shorter response times relative to those of vegetation. A case study of the modern speleothem geochemistry near our study area implies maximum response times of a few months to rainfall events during rainy summers ${ }^{56}$. Therefore, the discovery of lags between biotic (PqPann data of GG19-2-1) and abiotic ( $\delta^{18} \mathrm{O}$ data of $\left.\mathrm{BN}-1\right)$ responses in this study are strongly supported by the results of Williams et al. ${ }^{40}$, who reported a vegetation response time of 60 years in the most highly significant 


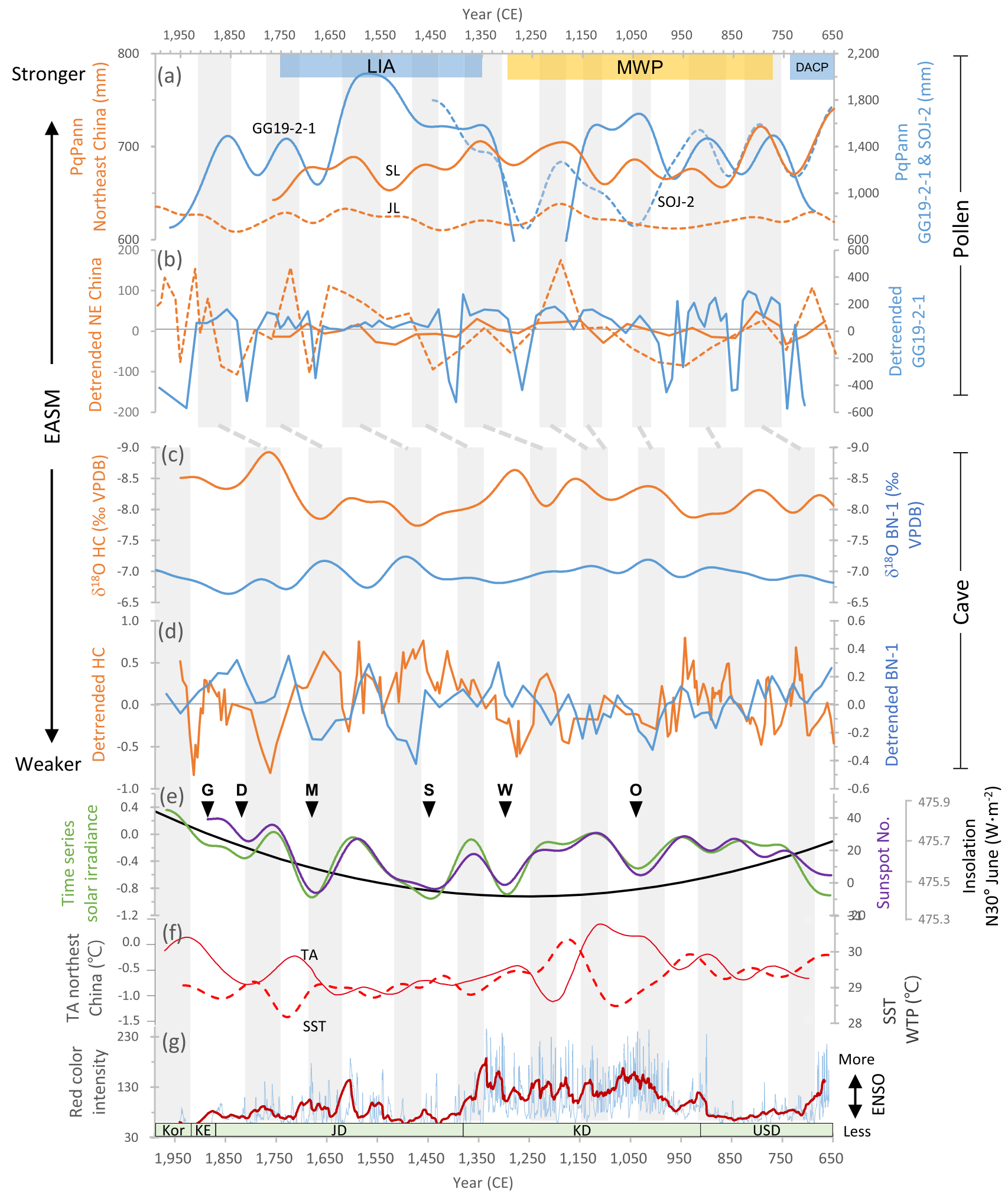


4Figure 4. Multi-centennial dry-wet periods and time-series lags of biotic (pollen) and abiotic (speleothem) responses to rainfall over the past 1300 years in East Asia. (a) PqPann of Korean ${ }^{18}$ (GG19-2-1 sediment core, solid blue line) and Chinese ${ }^{27,32}$ pollen data. SL (solid brown line), Sihailongwan Lake. JL (dashed brown line), Jingpo Lake; SOJ-2 (dashed blue line), Songji Lake. (b) Detrended fluctuations of PqPann showing the frequency, amplitude, and duration of Pann at four sites. All colors and lines have the same meaning as in Fig. 4 (a). (c) $\delta^{18} \mathrm{O}$ of the Korean Baeg-nyeong Cave ${ }^{9}$ and Chinese Heshang Cave ${ }^{33}$. A low $\delta^{18} \mathrm{O}$ corresponds to a strong EASM. (d) Detrended fluctuations of the two caves showing the amplitude and duration of the high precipitation interval. (e) Time series of solar irradiance ${ }^{70}$, number of sunspots ${ }^{50}$, and insolation at N $30^{\circ}$ in June $^{35}$ showing synchronous fluctuations. Upper case letters indicate grand solar minima: O, Oort; W, Wolf; S, Spörer; M, Maunder; D, Dalton; G, Gleissberg. (f) Temperature anomaly $\left({ }^{\circ} \mathrm{C}\right)$ of northeast $\mathrm{China}^{7}$ and sea surface temperature $\left({ }^{\circ} \mathrm{C}\right)$ of the western tropical Pacific ${ }^{71}$. (g) ENSO intensity from the Southern Hemisphere ${ }^{72}$ with 100-point moving average values (thick purple line). Light-gray bars indicate the high-precipitation periods represented by the Korean PqPann (GG19-2-1) and speleothem (BN-1) data. EASM, East Asian Summer monsoon; ENSO, El Niño-Southern Oscillation. The Korean chronology is plotted at the bottom. Kor, Korea; KE, Korea Empire; JD, Joseon Dynasty; KD, Koryŏ Dynasty; and USD, Unified Silla Dynasty (drawn using CorelDRAW Graphics Suite X7).

cross-correlation among lake sediments and a median lag time of 90 years among all significant cross-correlations between pollen and $\delta^{18} \mathrm{O}$ and chironomid assemblages.

In an ecological context, changes on a multi-decadal time scale in response to climate oscillations represent no more than a few population cycles for many arboreal taxa ${ }^{40}$. However, we suggest that the reconstruction of decadal- to centennial-scale climatic oscillations should be taken into account in determining biotic lags, even though they can be ignored in the reconstruction of millennial-scale climatic variability. Our new finding can be used to predict shifts in vegetation responses to climatic changes such as rapid warming or cooling under conditions of global warming.

\section{Methods}

The Gonggeom-ji paleo-reservoir is located inland in central South Korea $\left(36^{\circ} 30^{\prime} 46^{\prime \prime} \mathrm{N}, 128^{\circ} 09^{\prime} 39^{\prime \prime} \mathrm{E}\right.$, elevation $64 \mathrm{~m}$ above sea level) (Fig. 1). The 7-m-long GG19-2-1 sediment core obtained from Gonggeom-ji consists mainly of medium to coarse sand in the lower section, gray to dark-gray laminated clayey silt in the middle section, and oxidized brown mottled and laminated clayey silt in the upper section (Supplementary Figure S1).

The GG19-2-1 sediment core was dated by accelerator mass spectrometry (AMS) analysis of ${ }^{14} \mathrm{C}$ in eight plant samples held by the Korea Institute of Geoscience and Mineral Resources, and calendric ages were recalculated using CalPal-2007Online ${ }^{57}$ (Supplementary Table S1). The ${ }^{137} \mathrm{Cs}$ activity was measured in eight soil samples taken at 2.5-cm intervals from the upper Sect. (1.1-1.3 m) of the core, excluding the disturbed soil layer (Supplementary Figure S1). The depth at which ${ }^{137} \mathrm{Cs}$ activity was first detected, $1.225 \mathrm{~m}$, was assigned to the year 1963. An age-depth model was constructed using the $\mathrm{R}$ package $\mathrm{Clam}^{58}$ and IntCal13 radiocarbon calibration curve ${ }^{59}$ analysis, i.e., AMS analysis of the ${ }^{14} \mathrm{C}$ and ${ }^{137} \mathrm{Cs}$ activity of eight samples.

Fifty-five samples of the GG19-2-1 sediment core were taken for pollen analysis at 10-cm intervals from 1.0 to $6.5 \mathrm{~m}$. Pollen was extracted using a standard palynological method ${ }^{60}$. Two tablets containing exotic Lycopodium spores $(27,637$ per tablet) were added to each dry sample $(2-4 \mathrm{~g})$ to calculate the palynological concentration per gram of sample ${ }^{61}$. A pollen diagram with local pollen assemblage zones was produced using Tilia software ${ }^{62}$ (Supplementary Figure S2).

Annual precipitation over the last 1300 years was quantitatively reconstructed based on the subfossil AP records using CREST software ${ }^{63}$ and the CREST-formatted GBIF database ${ }^{64}$. The dataset contains the records of plants with quarter-degree grid cell resolution; we used 5,123 plant distribution records within 450 grid cells, which correspond to the geographical range of the KP. To determine the rationality of the PqPann reconstruction, we compared the instrumental rainfall and historic drought records (Fig. 2a-c) and reconstructed the precipitation index in the central inland and northeast coast areas from sediment, cave, and microfossil proxy data (Fig. 2d-f). The sand contents of cores KL-28 and KL-2922,65, which were used as indicators of the Holocene precipitation intensity, were chosen as input variables (Fig. 2b). Both of these cores, and the GG19-2-1 core, are located at the same latitude in the central inland region of the KP, and appear to have experienced similar climate changes during the late Holocene. The sand contents of the two cores were interpolated linearly according to the age of the pollen data.

The age-depth model ${ }^{58}$, together with the considered core section showing an uneven irregular erosional surface and dramatic shifts of grain size $(\mu \mathrm{m})$ and mean Folk and Ward $(\Phi)$, indicated a 660-year hiatus at a depth of $3.5 \mathrm{~m}$ in the core sample (Supplementary Figure S1). An ANNs was used to reconstruct Pann for the hiatus section of the GG19-2-1 sediment core using Visual Gene Developer 1.9 build $785^{66}$ (Fig. $2 \mathrm{c}$ ). The structure of the ANNs was designed with two hidden layers. PqPann and ANNs precipitation data were highly correlated with each other $\left(R^{2}=0.955\right)$ (Supplementary Figure S3a). The sand contents of core KL-2922, which were used as indicators of the Holocene precipitation intensity, were chosen as the input variables (Fig. 2b). The neural network was trained with a back-propagation algorithm using a hyperbolic tangent transfer function.

We used a Butterworth low-pass-filter to determine the periodicity of precipitation variability and performed cross-correlation analysis to identify the lag time between biotic and abiotic responses to precipitation. We performed power spectral analysis of the ANNs and $\mathrm{BN}-1 \delta^{18} \mathrm{O}$ data to determine the optimal Butterworth low-passfilter value. Power spectral analysis of the ANNs and $\mathrm{BN}-1 \delta^{18} \mathrm{O}$ data for the last 1300 years (650-1940 CE) yielded periodicities of ca. 90-150 years, ranging from 93 to 144 years and from 117 to 144 years (above the 95\% confidence level), respectively (Supplementary Figure S4). Based on these results, a 100-year Butterworth low-pass 
filter was applied (Fig. 2d,e,f) using the R package signal ${ }^{67}$. We also performed cross-correlation analysis (Fig. 3 and S3) using BINCOR ${ }^{68}$, to determine the lag time between the biotic and abiotic responses to precipitation.

Received: 18 May 2020; Accepted: 6 October 2020

Published online: 20 October 2020

\section{References}

1. Ljungqvist, F. C. A new reconstruction of temperature variability in the extra-tropical northern hemisphere during the last two millennia. Geogr. Ann. Ser. A, Phys. Geogr. 92, 339-351 (2010).

2. Wang, Y. et al. The holocene asian monsoon: links to solar changes and north atlantic climate. Science 80(308), 854-857 (2005).

3. Zhang, P. et al. A test of climate, sun, and culture relationships from an 1810-year Chinese cave record. Science 80(322), 940-942 (2008).

4. Wang, X. et al. Climate, desertification, and the rise and collapse of China's historical dynasties. Hum. Ecol. 38, 157-172 (2010).

5. Paulsen, D. E., Li, H.-C. \& Ku, T.-L. Climate variability in central China over the last 1270 years revealed by high-resolution stalagmite records. Quat. Sci. Rev. 22, 691-701 (2003).

6. Lee, H. \& Zhang, D. Space-time integration in geography and GIScience. Space-time integration in geography and giscience: research frontiers in the US and China (Springer Netherlands, 2015). https://doi.org/10.1007/978-94-017-9205-9.

7. Jia, D., Li, Y. \& Fang, X. Complexity of factors influencing the spatiotemporal distribution of archaeological settlements in northeast China over the past millennium. Quat. Res. 89, 413-424 (2018).

8. Lee, U. The comparative historical study on the weather characteristics in the second half of the 15th century. Korean Stud. 21, 389-415 (2012).

9. Jo, K. et al. 1000-Year quasi-periodicity of weak monsoon events in temperate northeast Asia since the mid-Holocene. Sci. Rep. 7, 15196 (2017).

10. Jo, K. et al. Mid-latitude interhemispheric hydrologic seesaw over the past 550,000 years. Nature 508, 378-382 (2014).

11. Lee, E. et al. Multi-proxy records of Holocene hydroclimatic and environmental changes on the southern coast of South Korea. Palaeogeogr. Palaeoclimatol. Palaeoecol. 545, 109642 (2020).

12. Park, J. Solar and tropical ocean forcing of late-Holocene climate change in coastal East Asia. Palaeogeogr. Palaeoclimatol. Palaeoecol. 469, 74-83 (2017).

13. Constantine, M., Kim, M. \& Park, J. Mid- to late Holocene cooling events in the Korean Peninsula and their possible impact on ancient societies. Quat. Res. 92, 98-108 (2019).

14. Lim, J. et al. Holocene coastal environmental change and ENSO-driven hydroclimatic variability in East Asia. Quat. Sci. Rev. 220, 75-86 (2019).

15. Yum, J. G., Takemura, K., Tokuoka, T. \& Yu, K. M. Holocene environmental changes of the Hwajinpo Lagoon on the eastern coast of Korea. J. Paleolimnol. 29, 155-166 (2003).

16. Cheung, R. C. W. et al. Decadal- to centennial-scale East Asian summer monsoon variability over the past millennium: An oceanic perspective. Geophys. Res. Lett. 45, 7711-7718 (2018).

17. Fujiki, T. \& Yasuda, Y. Vegetation history during the Holocene from Lake Hyangho, northeastern Korea. Quat. Int. 123-125, 63-69 (2004).

18. Song, B. et al. Pollen record of the mid- to late-Holocene centennial climate change on the East coast of South Korea and its influential factors. J. Asian Earth Sci. 151, 240-249 (2018).

19. Hwang, S., Kim, J.-Y. \& Kim, S. Environmental changes and embankment addition of Reservoir Gonggeomji, Sangju City between Late Silla- and Early Goryeo dynasty. J. Korean Geomorphol. Assoc. 21, 165-180 (2014).

20. Jhun, J. \& Moon, B. Restorations and analyses of rainfall amount observed by Chukwookee. Asia-Pacific J. Atmos. Sci. 33, 691-707 (1997).

21. Yoo, C., Park, M., Kim, H. J. \& Jun, C. Comparison of annual maximum rainfall events of modern rain gauge data (1961-2010) and Chukwooki data (1777-1910) in Seoul Korea. J. Water Clim. Chang. 9, 58-73 (2018).

22. Lim, J., Lee, J.-Y., Hong, S.-S. \& Kim, J.-Y. Late Holocene flooding records from the floodplain deposits of the Yugu River South Korea. Geomorphology 180-181, 109-119 (2013).

23. Li, J. et al. Quantitative Holocene climatic reconstructions for the lower Yangtze region of China. Clim. Dyn. 50, 1101-1113 (2018).

24. Sun, J. et al. Quantitative precipitation reconstruction in the east-central monsoonal China since the late glacial period. Quat. Int. 521, 175-184 (2019).

25. Stebich, M. et al. Holocene vegetation and climate dynamics of NE China based on the pollen record from Sihailongwan Maar Lake. Quat. Sci. Rev. 124, 275-289 (2015).

26. Li, J. et al. East Asian summer monsoon precipitation variations in China over the last 9500 years: A comparison of pollen-based reconstructions and model simulations. The Holocene 26, 592-602 (2016).

27. Cao, X. et al. Impacts of the spatial extent of pollen-climate calibration-set on the absolute values, range and trends of reconstructed Holocene precipitation. Quat. Sci. Rev. 178, 37-53 (2017).

28. Wu, D. et al. Decoupled early Holocene summer temperature and monsoon precipitation in southwest China. Quat. Sci. Rev. 193, 54-67 (2018).

29. Park, J. A modern pollen-temperature calibration data set from Korea and quantitative temperature reconstructions for the Holocene. The Holocene 21, 1125-1135 (2011).

30. Tian, F. et al. Pollen-climate relationships in time ( $9 \mathrm{ka}, 6 \mathrm{ka}, 0 \mathrm{ka})$ and space (upland vs. lowland) in eastern continental Asia. Quat. Sci. Rev. 156, 1-11 (2017).

31. Herzschuh, U. et al. Position and orientation of the westerly jet determined Holocene rainfall patterns in China. Nat. Commun. 10, 2376 (2019).

32. Li, C., Wu, Y. \& Hou, X. Holocene vegetation and climate in Northeast China revealed from Jingbo Lake sediment. Quat. Int. 229, 67-73 (2011).

33. Hu, C. et al. Quantification of Holocene Asian monsoon rainfall from spatially separated cave records. Earth Planet. Sci. Lett. 266, 221-232 (2008).

34. Wen, R. et al. Holocene precipitation and temperature variations in the East Asian monsoonal margin from pollen data from Hulun Lake in northeastern Inner Mongolia China. Boreas 39, 262-272 (2010).

35. Berger, A. \& Loutre, M. F. Insolation values for the climate of the last 10 million years. Quat. Sci. Rev. 10, 297-317 (1991).

36. Zhao, K. et al. Contribution of ENSO variability to the East Asian summer monsoon in the late Holocene. Palaeogeogr. Palaeoclimatol. Palaeoecol. 449, 510-519 (2016).

37. Giry, C. et al. Mid- to late Holocene changes in tropical Atlantic temperature seasonality and interannual to multidecadal variability documented in southern Caribbean corals. Earth Planet. Sci. Lett. 331-332, 187-200 (2012).

38. Viles, H. Interannual, decadal and multidecadal scale climatic variability and geomorphology. Earth-Science Rev. 61, 105-131 (2003). 
39. Lim, J. \& Fujiki, T. Vegetation and climate variability in East Asia driven by low-latitude oceanic forcing during the middle to late Holocene. Quat. Sci. Rev. 30, 2487-2497 (2011).

40. Williams, J. W., Post, D. M., Cwynar, L. C., Lotter, A. F. \& Levesque, A. J. Rapid and widespread vegetation responses to past climate change in the North Atlantic region. Geology 30, 971 (2002).

41. Yu, Z. Late quaternary dynamics of tundra and forest vegetation in the southern niagara escarpment Canada. New Phytol. 157, 365-390 (2003).

42. Yu, Z. Rapid response of forested vegetation to multiple climatic oscillations during the last deglaciation in the northeastern United States. Quat. Res. 67, 297-303 (2007).

43. Richter, H. \& Kituta, S. Ecophysiology of long-distance water transport in trees. in Trees in a Changing Environment- Ecophysiology, Adaptation, and Future Survival (eds. Tausz, M. \& Grulke, N.) (Springer Nature, 2014).

44. Johnson, M. T. \& Agrawal, A. A. The ecological play of predator-prey dynamics in an evolutionary theatre. Trends Ecol. Evol. 18, 549-551 (2003).

45. Tobolski, K. \& Ammann, B. Macrofossils as records of plant responses to rapid Late Glacial climatic changes at three sites in the Swiss Alps. Palaeogeogr. Palaeoclimatol. Palaeoecol. 159, 251-259 (2000).

46. Ammann, B. Biotic responses to rapid climatic changes. Palaeogeogr. Palaeoclimatol. Palaeoecol. 159, 191-201 (2000).

47. Walther, G. et al. Ecological responses to recent climate change. Nature 416, 389-395 (2002).

48. Lischke, H., Lotter, A. F. \& Fischlin, A. Untangling a Holocene pollen record with forest model simulations and independent climate data. Ecol. Modell. 150, 1-21 (2002).

49. Steinhilber, F., Beer, J. \& Fröhlich, C. Total solar irradiance during the Holocene. Geophys. Res. Lett. 36, L19704 (2009).

50. Solanki, S. K., Usoskin, I. G., Kromer, B., Schüssler, M. \& Beer, J. Unusual activity of the Sun during recent decades compared to the previous 11,000 years. Nature 431, 1084-1087 (2004).

51. Yi, S. \& Kim, J.-Y. Pollen analysis at Paju Unjeong, South Korea: Implications of land-use changes since the late Neolithic. The Holocene 22, 227-234 (2012).

52. Yi, S., Yang, D.-Y. \& Jia, H. Pollen record of agricultural cultivation in the west-central Korean Peninsula since the Neolithic Age. Quat. Int. 254, 49-57 (2012).

53. Yi, S., Saito, Y., Zhao, Q. \& Wang, P. Vegetation and climate changes in the Changjiang (Yangtze River) Delta, China, during the past 13,000 years inferred from pollen records. Quat. Sci. Rev. 22, 1501-1519 (2003).

54. Kim, C. \& Cheong, K. Research Report of Antiquities Vol. 204: Gonggeomji. Gyeongsangbukdo Institute of Cultural Properties, 230 $\mathrm{p}$ (2013) (in Korean).

55. Ammann, B. et al. Quantification of biotic responses to rapid climatic changes around the Younger Dryas- a synthesis. Palaeogeogr. Palaeoclimatol. Palaeoecol. 159, 313-347 (2000).

56. Jo, K., Woo, K. S., Hong, G. H., Kim, S. H. \& Suk, B. C. Rainfall and hydrological controls on speleothem geochemistry during climatic events (droughts and typhoons): an example from Seopdong Cave, Republic of Korea. Earth Planet. Sci. Lett. 295, 441-450 (2010).

57. Danzeglocke, U., Joris, O. \& Weninger, B. CalPal-2007online. Available at: https://www.calpal-online.de.

58. Blaauw, M. Methods and code for 'classical' age-modelling of radiocarbon sequences. Quat. Geochronol. 5, 512-518 (2010).

59. Reimer, P. J. et al. IntCal13 and Marine13 radiocarbon age calibration curves 0-50,000 years cal BP. Radiocarbon 55, 1869-1887 (2013).

60. Moore, P. D., Webb, J. A. \& Collison, M. E. Pollen Analysis 2nd edn. (Blackwell Scientific Publications, Oxford, 1991).

61. Stockmarr, J. Tablets with spores used in absolute pollen analysis. Pollen Spores 13, 615-621 (1971).

62. Grimm, E. Tilia 1.7.16 Software. Illinois State Museum, Research and Collection Center, Springfield, II. (2011).

63. Chevalier, M., Cheddadi, R. \& Chase, B. M. CREST (Climate REconstruction SofTware): a probability density function (PDF)based quantitative climate reconstruction method. Clim. Past 10, 2081-2098 (2014).

64. Chevalier, M. Enabling possibilities to quantify past climate from fossil assemblages at a global scale. Glob. Planet. Change 175, $27-35$ (2019).

65. Lim, J., Yi, S., Nahm, W.-H. \& Kim, J.-Y. Holocene millennial-scale vegetation changes in the Yugu floodplain, Kongju area, central South Korea. Quat. Int. 254, 92-98 (2012).

66. Jung, S.-K. \& McDonald, K. Visual gene developer: a fully programmable bioinformatics software for synthetic gene optimization. BMC Bioinformatics 12, 340 (2011).

67. Singal developer. Signal: Signal processing. (2013).

68. Polanco-Martinez, Josue, M., Medina-Elizalde, Martin, A., Goni, Maria, Fernanda, S. \& Mudelsee, M. BINCOR: An R package for Estimating the Correlation between Two Unevenly Spaced Time Series. R J. 11, 170 (2019).

69. Yim, T. \& Kira, T. Distribution forest vegetation and climate in the Korea Peninsula. I. Distribution of some indices of thermal climate. Japanese J. Ecol. 25, 77-88 (1975).

70. Steinhilber, F. et al. 9,400 years of cosmic radiation and solar activity from ice cores and tree rings. Proc. Natl. Acad. Sci. 109, 5967-5971 (2012).

71. Stott, L. et al. Decline of surface temperature and salinity in the western tropical Pacific Ocean in the Holocene epoch. Nature 431, 56-59 (2004).

72. Moy, C. M., Seltzer, G. O., Rodbell, D. T. \& Anderson, D. M. Variability of El Niño/Southern Oscillation activity at millennial timescales during the Holocene epoch. Nature 420, 162-165 (2002).

\section{Acknowledgements}

This research was supported by a Basic Research Project (GP2020-003) of the Korea Institute of Geoscience and Mineral Resources funded by the Ministry of Science and ICT, Korea, and was performed as part of the "Paleoenvironmental reconstruction based on biological analysis from Korean wetland sediments" project (NNIBR202001104). We thank the two anonymous reviewers for their constructive comments. We thank C. Li for providing the Lake Jingpo pollen data and Prof. M. Yasuhara for providing the Hwajinpo Lake foraminifera data. The data used in this study are available in the supporting information, and from the NOAA Paleoclimatology database (https://www.ncdc.noaa.gov/data-access/paleoclimatology-data).

\section{Author contributions}

S. Y. designed the study, drafted the manuscript, and analyzed palynomorphs. C.-P. J., K. J., M.-S. K., and X. C. contributed to the statistical analyses and discussion. H. L., S. D. L., and J. L. contributed to the dating, grain size analysis, and discussion.

\section{Competing interests}

The authors declare no competing interests. 


\section{Additional information}

Supplementary information is available for this paper at https://doi.org/10.1038/s41598-020-74994-X.

Correspondence and requests for materials should be addressed to S.Y. or C.-P.J.

Reprints and permissions information is available at www.nature.com/reprints.

Publisher's note Springer Nature remains neutral with regard to jurisdictional claims in published maps and institutional affiliations.

Open Access This article is licensed under a Creative Commons Attribution 4.0 International

License, which permits use, sharing, adaptation, distribution and reproduction in any medium or format, as long as you give appropriate credit to the original author(s) and the source, provide a link to the Creative Commons licence, and indicate if changes were made. The images or other third party material in this article are included in the article's Creative Commons licence, unless indicated otherwise in a credit line to the material. If material is not included in the article's Creative Commons licence and your intended use is not permitted by statutory regulation or exceeds the permitted use, you will need to obtain permission directly from the copyright holder. To view a copy of this licence, visit http://creativecommons.org/licenses/by/4.0/.

(c) The Author(s) 2020 